Sharif University of Technology
Scientia Iranica
SCIENTIA
IRANICA
Transactions A: Civil Engineering
www.scientiairanica.com

\title{
Integrated construction waste management, a holistic approach
}

\author{
M.M. Mortaheb* and A. Mahpour \\ Department of Civil Engineering, Sharif University of Technology (SUT), Tehran, Iran.
}

Received 24 November 2015; received in revised form 1 February 2016; accepted 16 April 2016

\begin{abstract}
KEYWORDS
Integrated

construction waste

management;

Sustainable

development;

Constructability;

Construction and

demolition waste;

construction waste

reduction.
\end{abstract}

\begin{abstract}
The objective of the present study is to depict an inclusive Construction Waste Management (CWM) plan looking at the total project life cycle. This holistic approach is called Integrated Construction Waste Management (ICWM). This research program has been conducted through several consecutive academic dissertations at Civil Engineering Department of SUT and was firstly aimed to identify waste sources throughout project life cycle. Concurrent research efforts were focused on project delivery methods evaluation, e.g. contract type effect on waste generation amount along with appropriate guidelines/incentives development that could promote ICMW. These studies were conducted via field observations and questionnaire surveys where respondents were educated, skilled, and experienced construction industry experts. The research findings indicate that construction waste origins/processes should be determined separately during the life cycle of construction projects to devise exclusive solutions accordingly. Furthermore, cost-plus contract, which is common in local residential projects in Iran, is identified as an improper contract type from construction waste generation standpoint. Incentive based programs, project stakeholders training, salvage plan establishing for all materials before project initiation, and apt documentation for future CWM planning are identified as effective/practical ICWM solutions. Finally, it is concluded that thriving ICWM is going to be a teamwork result rather than responsibility of a sole stakeholder, e.g. contractor.
\end{abstract}

(C) 2016 Sharif University of Technology. All rights reserved.

\section{Introduction}

Construction industry plays a major role in enhancing competitiveness and prosperity in the world economy. The design, construction, operation, and utilization phases of the built environment have important economic as well as sustainability effects. Modern and efficient built environment is a key driver of productivity and growth in every economy. Therefore, the construction industry is facing a challenge in delivering the built environment in an effective and optimized

* Corresponding author. Tel.: +98 2166164266 ; Fax: +982166013201

E-mail addresses: mortaheb@sharif.edu (M.M. Mortaheb); mahpour_amirreza@mehr.sharif.ir (A. Mahpour) manner, in order to maintain its share in the economy while coping with the global sustainability rules and regulations. The construction industry has significant impact on the environment during execution of every phase of the project's life cycle. It consumes enormous amounts of raw materials and respectively produces considerable waste during construction, renovation, and/or demolition phases of the project. Studies estimate that construction industry consumes around a quarter of all raw materials used in the world economy. It also produces up to one third of total landfill wastes with a 1:2 ratio of construction to demolition waste [1$3]$. Only a fraction of the produced waste is currently recycled or reclaimed. These statistics imply the importance of CWM and, most recently, growing concerns about the sustainability of construction activities have 
brought the issue of Construction Waste Management (CWM) to the fore. CWM is any effort, including legislation, supervision, fining or reward based programs, etc., done in order to reduce, minimize, or control construction waste generation [4]. Similarly, construction waste minimization is planning for reducing avoidable construction waste during different phases of construction projects, especially construction phase [5].

ICWM is balancing the environmental demands of a project with the economic ones, which reflects currently accessible CWM solutions like reduction, recycling, reusing, incineration, landfilling, and composting that are being investigated and developed in different parts of the world. In other words, ICWM is a comprehensive construction waste prevention, recycling, composting, and disposal program. This program can be done by urban and project managers via legislation, more strict supervision, fining or rewarding policies, and many other methods [6-8]. Construction industry, by its very nature, while contributes to the economic aspect of sustainable development, is detrimental to sustainable environment. The aim of this research is to integrate the previous studies done by authors on identification, management, and reduction solutions of construction waste [9-12]. By enhancing the efficiency in using resources, the construction industry can play a central role to promote sustainable growth and development. Sustainable development is defined as "Meeting the needs of the present, without compromising the needs of future generations" [13]. However, policy makers and practitioners tend to forget the other two dimensions of sustainable development - environmental and social - during planning and implementation of construction projects [14]. In developed countries, standards, guidelines, and regulations have been designed to address the issue of CWM. However, despite consequences and adverse impacts that excessive production of Construction and Demolition Waste imposes on sustainable development, little care has been given to the implementation of CWM practices in undeveloped and even developing countries. As a result, the construction industry has not made satisfactory progress towards achieving sustainability goals. For instance, the ultimate product of today's construction industry is the built environment designed and constructed without any consideration for dismantling and reuse at the end of its life cycle [15].

Construction waste, as disposed or not useful materials during execution of projects, is one of the current serious environmental concerns. High amounts of material wastage exert several detrimental effects on economy, environment, and society. Lack of comprehensive and practical frameworks to help project managers implement such holistic plans in construction projects, especially in developing countries where traditional construction methods are common, is still palpable. Construction waste can be addressed in two different ways, i.e. waste minimization and waste management, during the project life cycle from initiation to demolition.

\subsection{Literature review}

Kern et al. (2015) conducted a multiple-regressionbased study and evolved a model estimating the Construction Waste Generation (CWG) in high-rise buildings construction in Brazil. In this research, the production system and design process are deemed to be salient influential parameters in estimating CWG [16]. Sáez et al. (2015) investigated the total floor area of the project and number of dwellings simultaneously and studied several newly built residential buildings. They proposed a novel quantification model in terms of volume and weight for CWG in the Mediterranean buildings [17]. Ding and Xiao (2014) quantified Construction and Demolition Waste (C\&DW) generation in buildings in Shanghai, China, by scrutinizing the outcomes of structure design and affiliated structure codes in several decades on fluctuations of CWG and structure type [18]. Based on mass balance principle for construction, Li et al. (2013) generated a model quantifying waste generation per gross FA (WGA) in China. In this model, WGAs for materials are computed based on the purchased amount and waste rate of materials. In addition, the WGA for minor quantities of materials is obtained as a percentage of total CW. This suggested model is applied to construction of a residential building in Shenzhen, China [19]. Banias et al. (2011) conducted a case study of five apartment buildings in Thessaloniki, Greece, in order to quantify twenty one distinct C\&DW streams for different sorts of buildings including industrial, residential, office, and commercial. With respect to economic and environmental criteria, a web based decision support system application, called Decon RCM, empowers user to optimize end of life management alternatives using mathematical programming [20]. A quantitative model is developed by analyzing more than twenty buildings in a Spanish case study by Llatas (2011). This model promotes prevention and recovery of $\mathrm{CW}$, and permits to find the origin of the waste and adapt other alternative procedures eliminating hazardous waste and reducing CW. Furthermore, it makes estimation of C\&DW during the design phase possible. By analytical expressions based on the factors obtained by studying the buildings, a systematic structure of the construction process and a system for waste division are engendered as well. Results imply that prosperous implementation of the model in construction projects will yield enhancement of the opportunities of C\&DW reduction and recovery [21]. Cochran and Townsend (2010) applied a materials flow analysis approach 
and used Building Materials (BMs) and typical waste factors used for BMs supplying to quantify C\&DW generation in USA [22]. Katz and Baum (2010) estimated $\mathrm{CWG}$ in residential construction sites by means of a method they developed. They researched in three steps: field observations, data collection, and development of the model. The results are believed to be helpful for CWM practices akin to enforcement systems or taxation [23]. Udwatta et al. (2015) determined effective approaches to eliminate and/or minimize waste generation in construction projects. Their findings revealed 26 critical solutions for waste management, such as using construction technologies and proper selection of materials [24]. Butera et al. (2015) quantified the environmental impacts of C\&DW utilized in road construction and compared the results of the study with landfilled C\&DW. The results indicated that using C\&DW in road construction was less detrimental to environment than landfilling them [25].

\subsection{The research gap}

Examining the available literature and consulting the experts show that whilst there are several articles, instructions, and manuals addressing the issue of construction waste, waste management programs are not integrated effectively into most of the construction projects. This is partly because current policies, procedures, and methods do not address the issue holistically. They do not take all aspects of a project, i.e. all its phases, work resources, and activities, into consideration. Lack of practical frameworks to help project managers to implement the concepts and practices of CWM in projects is a gap that has to be filled through research and development. Therefore, more holistic studies are needed to address the concepts and principles of CWM. This paper provides an overview of the research endeavors aimed at enhancing the state of knowledge and practice in devising and implementing of appropriate construction waste minimization and management practices in the construction industry. In this context, management of waste is defined as eliminating waste to the maximum possible extent (eliminating avoidable waste) by minimizing waste where feasible and reusing materials that might otherwise become wasted. Solid waste management practices have identified reduction, recycling, and reuse of wastes essential for sustainable management of resources. Comprehensive studies conducted by the authors during the last several years include, but are not limited to, the following topics.

\subsubsection{Construction waste management: An approach to improve construction productivity}

The objective of this study [26] was to enhance the understanding about CWM practices and improve construction productivity as well as promote sustainable development. Through a comprehensive literature review, concepts such as project productivity, sustainable development, whole life cycle paradigm, and hierarchy were analyzed. The review of literature shows that the amount of construction waste, even in most developed countries, is high. Nevertheless, it is found out that in the developed world, significant efforts have been dedicated to the development of appropriate policies and regulations as well as manuals and instruction on the CWM topic.

Following the review of related literature, a frame of reference to shift the current paradigm in industry to "construct with minimum waste" was developed, as displayed in Tables 1 to 3 . Furthermore, Table 4 represents the results of a successful financial incentive based scheme implemented in Hong Kong, China. Finally, Table 5 shows the results of elasticity analysis of construction materials wastage reduction in Tehran, Iran. This paradigm identifies and discusses CWM considerations through whole project life cycle, i.e. from feasibility studies to the start-up and operation of the finally built structure.

CWM Paradigm is the frame of reference by which decision makers of the project would effectively contribute to decreasing the amount of waste generated through construction activities, which will in turn improve productivity of the project. Table 3 displays the summary of the survey. This summary table presents maps of CWM areas of concentration and proposes strategies for the project life cycle phases. A concentration area is a topic/issue that is of special importance when considering CWM, while proposed strategies, methods, tools, and techniques refer to special practical recommendations with regard to each concentration area.

It is recommended that constructors apply this frame of reference to optimize material usage. It should be noted that the implementation of this frame of reference requires no additional planning and/or resources. In addition to the introduction of the paradigm, a model based on the common lexicon provided by Project Management Body Of Knowledge (PMBOK) was developed. This model is shown in Table 2 and utilizes the same terminologies of PMBOK Guide lexicon. This model is intended to serve as a standard for project managers to implement CWM program in construction projects. In the process of developing this model, first, the feasibility of adding CWM concepts to Environmental Management knowledge area was examined. However, the scope of necessary changes as well as the importance and universality of CWM principles required the principles of CWM to treat as a separate knowledge area of construction extension. PMBOK guides, so far, have not addressed the importance of construction waste reduction or significance of CWM. Ultimately, this knowledge area can be suggested to 
Table 1. Mapping of CWM considerations and strategies for the phases of the project's life cycle.

\begin{tabular}{|c|c|c|}
\hline $\begin{array}{l}\text { Project } \\
\text { phases }\end{array}$ & $\begin{array}{l}\text { Construction } \\
\text { areas }\end{array}$ & $\begin{array}{l}\text { Proposed strategies, } \\
\text { methods, tools, and } \\
\text { techniques }\end{array}$ \\
\hline \multirow{3}{*}{$\begin{array}{l}\text { Feasibility } \\
\text { studies }\end{array}$} & Cost & $\begin{array}{l}\text { Cost-benefit analysis, value engineering } \\
\text { Life cycle costing } \\
\text { Recycled materials market analysis }\end{array}$ \\
\hline & Time & $\begin{array}{l}\text { Deconstruction parallel to design/engineering } \\
\text { Proper scheduling } \\
\text { Smarter, not slower, work (avoid complexity in } \\
\text { workers' duties) }\end{array}$ \\
\hline & Quality & $\begin{array}{l}\text { Assess and estimate the quality of recycled materials } \\
\text { Assess and estimate the quality of final products } \\
\text { (structures) }\end{array}$ \\
\hline \multirow{6}{*}{$\begin{array}{l}\text { Design and } \\
\text { engineering }\end{array}$} & Design/engineering philosophy & $\begin{array}{l}\text { Adoption of modern design systems, } \\
\text { e.g. modular design } \\
\text { Use of standard and simple shapes and sizes }\end{array}$ \\
\hline & Constructability analysis of design & $\begin{array}{l}\text { Design construction integration } \\
\text { Provide accurate, understandable, reliable blueprints }\end{array}$ \\
\hline & Design change and modifications & $\begin{array}{l}\text { Avoid frequent changes } \\
\text { Select change options with minimum demolition } \\
\text { and rework }\end{array}$ \\
\hline & Material construction & $\begin{array}{l}\text { Use prefabricated members } \\
\text { Use recycled materials }\end{array}$ \\
\hline & Estimating materials requirements & $\begin{array}{l}\text { Provide accurate destination for amount of } \\
\text { material delivery } \\
\text { Provide accurate destination for time of } \\
\text { material delivery }\end{array}$ \\
\hline & Job-site layout & $\begin{array}{l}\text { Allocate adequate, appropriate space to CWM equipment } \\
\text { Allocate adequate, appropriate space to collecting bins } \\
\text { Allocate adequate, appropriate space to inventory } \\
\text { Provide easy-access routes between inventory and workshop }\end{array}$ \\
\hline \multirow{5}{*}{ Procurement } & Materials and source selection & $\begin{array}{l}\text { Use durable materials } \\
\text { Use local resources }\end{array}$ \\
\hline & Supplier selection and management & $\begin{array}{l}\text { Stipulate take-back policies } \\
\text { Require reduction of packaging materials }\end{array}$ \\
\hline & Contractor selection and management & $\begin{array}{l}\text { Represent waste reduction requirements in the contract } \\
\text { Require the contractor to submit a CWM Plan } \\
\text { Require the contractor to document their waste reduction } \\
\text { Incorporate the CWM Plan into the contractor's QC/QA }\end{array}$ \\
\hline & Equipment and machinery selection & $\begin{array}{l}\text { Consider waste characteristics } \\
\text { Consider market specifications } \\
\text { Consider job-site space and layout }\end{array}$ \\
\hline & Ordering management & $\begin{array}{l}\text { Order in coordination with design/engineering unit } \\
\text { Deliver just in time }\end{array}$ \\
\hline
\end{tabular}


Table 1. Mapping of CWM considerations and strategies for the phases of the project's life cycle (continued).

\begin{tabular}{|c|c|c|}
\hline $\begin{array}{l}\text { Project } \\
\text { phases }\end{array}$ & $\begin{array}{l}\text { Construction } \\
\text { areas }\end{array}$ & $\begin{array}{l}\text { Proposed strategies, } \\
\text { methods, tools, and } \\
\text { techniques }\end{array}$ \\
\hline \multirow{9}{*}{$\begin{array}{l}\text { Construction/ } \\
\text { execution }\end{array}$} & Inventory management & $\begin{array}{l}\text { Allocate appropriate space and position to inventory } \\
\text { Provide proper sheltering against weather and } \\
\text { human factors } \\
\text { Provide easy-access routes to inventory }\end{array}$ \\
\hline & Transportation and on-site handling & $\begin{array}{l}\text { Hire experienced and reliable haulers } \\
\text { Maintain proper on-site supervision }\end{array}$ \\
\hline & Construction and demolition methods & $\begin{array}{l}\text { Prefabrication } \\
\text { Deconstruction } \\
\text { Improving efficiency of current methods }\end{array}$ \\
\hline & Mistakes, errors, and rework & $\begin{array}{l}\text { Provide clear, reliable blueprints } \\
\text { Maintain proper on-site supervision } \\
\text { Use advanced, reliable technologies } \\
\text { Perform periodic service and repair equipment } \\
\text { Keep job-site organized and safe }\end{array}$ \\
\hline & Job-site activities plan & $\begin{array}{l}\text { CWM Plan } \\
\text { CWM site activities plan }\end{array}$ \\
\hline & Job-site supervision & $\begin{array}{l}\text { Troubleshooting and on-site training/education } \\
\text { Change requests } \\
\text { Prepare periodic performance reports }\end{array}$ \\
\hline & Training and education & $\begin{array}{l}\text { Arrange and manage training sessions } \\
\text { Provide and distribute easy-to-understand instructions } \\
\text { Design and set job-site instructive signs and marks }\end{array}$ \\
\hline & Quality control & $\begin{array}{l}\text { Quality control/assurance of recycled materials } \\
\text { Quality control/assurance of final products (structures) }\end{array}$ \\
\hline & Prevent construction waste generation & $\begin{array}{l}\text { Devise merits for reducing construction waste and } \\
\text { use elasticity as a tool for control and prevent } \\
\text { construction waste generation }\end{array}$ \\
\hline Start-up & Job-site final clean-up & Collect unused materials after construction \\
\hline $\begin{array}{l}\text { Operation/ } \\
\text { utilization }\end{array}$ & Renovation and repair & $\begin{array}{l}\text { Deconstruction and careful dismantling } \\
\text { Reuse and recycle used materials }\end{array}$ \\
\hline
\end{tabular}

Table 2. Mapping of CWM processes of the process groups (format adopted from PMBOK* by Project Management Institute).

\begin{tabular}{|c|c|c|c|c|c|}
\hline \multirow{2}{*}{ Knowledge area } & \multicolumn{5}{|c|}{ Process groups } \\
\hline & Initiating & Planning & Executing & Controlling & Closing \\
\hline \multirow[t]{2}{*}{$\begin{array}{l}\text { Construction } \\
\text { waste } \\
\text { management }\end{array}$} & $\begin{array}{l}\text { Waste } \\
\text { identification } \\
\text { and analysis }\end{array}$ & $\begin{array}{c}\text { Waste } \\
\text { management } \\
\text { planning }\end{array}$ & $\begin{array}{c}\text { Training } \\
\text { and educational } \\
\text { programs }\end{array}$ & $\begin{array}{c}\text { Waste } \\
\text { management } \\
\text { program control }\end{array}$ & $\begin{array}{c}\text { Waste } \\
\text { management } \\
\text { program administration } \\
\text { and records }\end{array}$ \\
\hline & & $\begin{array}{l}\text { Resource } \\
\text { planning }\end{array}$ & $\begin{array}{c}\text { Waste management } \\
\text { plan execution }\end{array}$ & & \\
\hline
\end{tabular}


Table 3. The degree of influence of constructability ideas on productivity.

\begin{tabular}{lll}
\hline No. & \multicolumn{1}{c}{ Criteria } & Score (out of 5) \\
\hline 1 & Considering appropriate material sizing & 4.6 \\
2 & Design to simplify installation & 4.5 \\
3 & Design according to available resources and skills & 4.5 \\
4 & Providing clear details and technical specifications & 4.3 \\
5 & Evaluating project site location and environment & 4.2 \\
6 & The use of modeling and simulation to avoid difficulties during construction & 4.1 \\
7 & Evaluation of the possible juxtaposition of different materials due to allowable tolerances & 4.1 \\
8 & Encouraging for standardization and increasing modular activities & 4.0 \\
9 & Considering the location of the warehouse to minimize the need for handling & 4.0 \\
10 & materials at project site & 4.0 \\
11 & Design to minimize the work on levels below the ground surface & 4.0 \\
12 & Considering the interaction of climate with construction materials and methods & 4.0 \\
\hline
\end{tabular}

Table 4. Summary of the incentive based method.

\begin{tabular}{cccc}
\hline Stage & $\begin{array}{c}\text { Cost saved on } \\
\text { purchasing } \\
\text { material } \\
(\$)\end{array}$ & $\begin{array}{c}\text { Cost saved } \\
\text { on waste } \\
\text { generation } \\
(\$)\end{array}$ & $\begin{array}{c}\text { Percentages } \\
\text { of waste } \\
\text { generation } \\
\text { saved }\end{array}$ \\
\hline 1 & 173500 & 3230 & 4 \\
2 & 173500 & 7580 & 9 \\
3 & 173500 & 19030 & 23 \\
\hline
\end{tabular}

Table 5. Results of elasticity analysis of financial incentive in Tehran, Iran.

\begin{tabular}{ccccc}
\hline Material & $\begin{array}{c}\text { Average } \\
\text { wastage } \\
(\%)\end{array}$ & $\begin{array}{c}\text { Average } \\
\text { elasticity }\end{array}$ & $\begin{array}{c}\text { Economic } \\
\text { incentive } \\
\text { growth } \\
(\%)\end{array}$ & $\begin{array}{c}\text { Relative } \\
\text { wastage } \\
\text { reduction } \\
(\%)\end{array}$ \\
\hline Rebar & 1.358 & 0.424 & 1 & 31.22 \\
Concrete & 3.793 & 0.815 & 1 & 21.49 \\
Brick & 6.049 & 0.684 & 1 & 11.31 \\
Cement & 8.403 & 0.923 & 1 & 10.98 \\
\hline
\end{tabular}

be added to the future release of PMBOK Guide as an extension. CWM knowledge area includes the process required to ensure that construction projects are executed with appropriate care to reduce the waste materials headed to landfills. The proposed model recognizes seven processes in CWM knowledge area: waste identification and analysis, waste management planning, resource planning, training and educational programs, waste management plan execution, waste management program control, and waste management program administration and records. In Table 2, these processes are mapped into five major process groups of initiating, planning, executing, controlling, and closing.

The model is specifically developed for projects where CWM is recognized as a major program of the project portfolio similar to other programs such as the Health and Safety program. Finally, as a part of this research, a study aimed at characterizing the status of construction waste production and management in Tehran metropolitan area was conducted. In this study, a questionnaire including 59 questions was prepared using Likert scale and was distributed to construction experts. The experts were supposed to assign one of the scores of $0,0.25,0.50,0.75$, or 1 to each question. Then, the average of the scores of the same criterion obtained from reliable questionnaires was calculated and finally, a set of 59 criteria were prioritized. The criterion which gained the highest score was ranked the first and so on. The case study (Tehran metropolitan area) and the follow-up analysis led to the identification of a set of measures that could improve the current situation. Based on the findings of this analysis, in order to implement CWM principles in Iran's Construction Industry, the government should set out rules and provide instructions on the issue, while constructors must design structures for minimum waste and adopt modern construction methods like prefabrication or the mentioned economic merits.

Through several case studies, the factors affecting construction materials waste generation during supply chain (mainly perishable like Ready-Mix Concrete (RMC) and/or Hot-Mix Asphalt (HMA) at the construction site were carefully investigated and ranked. The 10 most important ones were found to be:

- Waste generated due to lack of modular or standard construction;

- Waste generated by non-recyclable packaging materials;

- Using low quality building utility components that would require early-age renovation; 
- Waste generated by untrained or unskilled workforce;

- Lack of an integrated CWM program in the project administration;

- Using low quality construction materials;

- Waste generated during transport to site or inside the site due to improper packaging;

- Waste generated by cut-to-fit due to design requirements and/or disorders;

- Waste due to over-stocked bulk materials at the site;

- Waste generated because of utilizing old or imprecision tools or equipment.

\subsubsection{Effect of constructability studies on construction waste generation}

During the construction of high-rise buildings, the project team issues such as changes, additional costs of duplication, lack of technical specifications in plans, safety, and delays may arise. One of the most effective ways to avoid these issues is constructability evaluation at the appropriate stages of project. There are several definitions for constructability. For instance, it has been defined as the optimal use of knowledge and practical experience in planning, design, and procurement in order to achieve the overall goal of the project [27]. Numerous studies have investigated the impact of conducting constructability reviews in construction projects. A study conducted by the Construction Industry Institute (CII) [28] showed that implementation of constructability reviews in five different projects has reduced the project duration by 11 to 30 percent. In addition, analysis of data from several projects has shown that by using constructability, time is reduced without resulting in any significant costs increase [29].

The objective of another study [30] was to examine the effectiveness of constructability and productivity reviews in high-rise building projects. Interviews with experts and questionnaires were used as the main tools to gain insight into this matter. The study first investigated the opportunity to implement constructability reviews in the design phase of highrise building projects. In the design phase, the constructability review should focus on the following areas:

- Evaluating project site location and environment in terms of architectural textures;

- Designing to minimize the work on levels below the ground surface;

- Designing to simplify installation;

- Encouraging standardization and increasing modular activities;

- Designing to improve and facilitate prefabrication;
- Utilizing modeling and simulation to avoid difficulties during construction [31];

- Evaluating the possible juxtaposition of different materials due to allowable tolerances;

- Planning to avoid problems in sequential activities;

- Considering the location of the warehouse to minimize the need of handling materials at project site;

- Designing according to available resources and skills;

- Considering appropriate material sizing;

- Providing clear details and technical specifications;

- Considering the interaction of climate with construction materials and methods.

Based on the areas of constructability reviews during the design phase, a questionnaire was prepared to survey the impact of constructability reviews on construction productivity in high-rise buildings. This questionnaire used Likert scale and was distributed to 42 construction experts. The objective of this survey was determining the degree of influence of constructability on productivity. The experts were requested to assign one of five scores from 1 to 5 to 12 criteria based on their experience and judgment. The responses to the questionnaire were analyzed using the average index method. Table 3 summarizes the survey results. The survey results indicated that, if conducted during the design phase, constructability reviews could enhance the productivity in high-rise building projects. It is recommended that, prior to the initiation of a project, the project management team develop appropriate guidelines and checklists for conducting constructability reviews.

Surveys show that the two main barriers to implement effective ICWM are:

- Lack of culture for saving the resource and/or optimum use;

- Lack of defined recycling scheme in the project administration.

Experts recommended strategies be developed in order for:

- Constructability Analysis to be performed at design stage;

- Industrial construction to be used and build quality to last longer;

- Reuse or recycle to be done when demolishing.

\subsubsection{Materials waste control through elasticity analysis and incentives}

A quantitative study was done in order to determine the priority of saving the resources and/or their optimum use. 
Firstly, the concept of elasticity could be proposed as a proper tool to devise effective policies. This concept is used to derive the results of another study by the authors that is displayed in Table 5. According to the definition of elasticity [32] for the independent variable of $X$ and dependent variable of $Y$, elasticity of variable $Y$ is calculated based on Eq. (1):

$$
E_{Y C}=\frac{\left(\frac{\partial Y}{Y}\right)}{\left(\frac{\partial C}{C}\right)}=\frac{\left(\frac{\Delta Y}{Y}\right)}{\left(\frac{\Delta C}{C}\right)} .
$$

Several researchers have investigated the applicability of this concept in various fields such as supply-demand adjustment, i.e. controlling of fuel consumption by analyzing the sensitivity of fuel consumption to its price, and have stated that this sensitivity could be determined by calculating $E_{F P}$ according to Eq. (1), where dependent variable is $F$ or fuel consumption and independent variable is $P$ or fuel price [33,34]. Furthermore, the concept of elasticity is assumed to be a good managerial tool to make decisions related to waste management, which persuaded the authors to use it in determining the most sensitive material to increasing financial incentive (summarized results in Table 5). For example, this concept has been studied in order to reduce the wastage of paper, too. Mansikkasalo et al. (2014) provided a critical survey of existing econometric analyses of supply and demand elasticity in recycled paper market and suggested Eq. (2) to estimate the supply of recycled paper [35]:

$$
R_{S}=\beta_{0}+\beta_{1} \cdot P_{R}+\sum_{1=2}^{M} \beta_{1} \cdot F_{1}+y .
$$

Eq. (2) is developed to manage paper waste and to analyze the recycled paper supply, where $R_{S}$ is recycled paper supply, $P_{R}$ is recycled paper price, $F_{l}$ is the vector containing any additional independent variables included in the demand and supply equations, $y$ is the error term, and $\beta_{1}$ is the coefficient of the variable $P_{R}$ [35]. The concept of elasticity can be effectively used in CWM, too.

Secondly, economic tools can be implemented to prevent or reduce construction waste generation. One of the important methods of economic tools is payment of incentive [12,36]. Tam and Tam (2008) developed a creative method to reduce construction waste generation in Hong Kong. In this proposed incentive based model, which is implemented in 3 levels as shown in Figure 1, the results mentioned in Table 4 are derived [36].

The amount of reward $(\Delta R)$ in this study is given in Eq. (3):

$$
\Delta R=C_{t} \cdot R \% \text {, }
$$

where $R \%$ is determined from Figure 1 and $C_{t}$ is total cost saved [36].

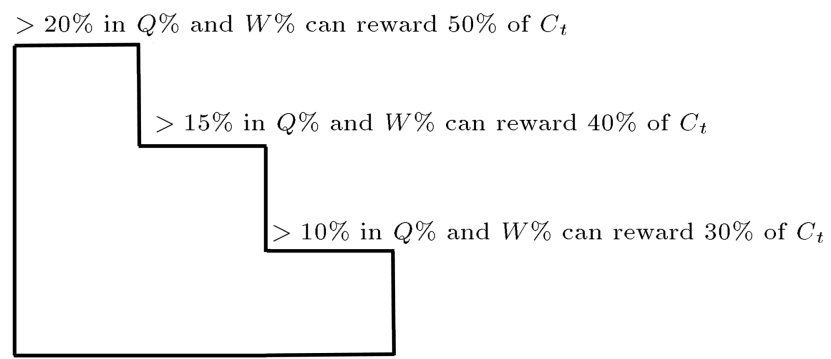

Figure 1. Stepwise incentive scheme $\left(C_{t}\right.$ : total cost saved, $Q \%$ : material quantity percentage saved, and $W \%$ : waste percentage saved).

Thirdly, a combination of financial incentive and its managing by means of elasticity can be proposed. Such study is done in Iran by authors and economic incentive is proposed to persuade contractors in order to reduce wastage of bulk materials. To do this, a questionnaire was prepared to gather quantities of the wastage amount of four commonly used bulk materials including rebar, concrete, brick, and cement in Tehran. Thirty two residential building projects were studied and wastage of these bulk materials was collected through field observations and measurement. Afterwards, sensitivity of wastage of studied materials was investigated by using elasticity concept. The results of elasticity analysis showing the effect of $1 \%$ increase in the payment of a financial incentive on wastage reduction of cement and 3 other materials are depicted in Table 5 [9].

According to the "average elasticity" amounts in the third column, increase in this kind of financial incentive is mostly effective on reduction of cement wastage.

\section{Other research efforts}

There are several recent research efforts focusing on CWM. An overview of these research efforts is presented below:

a) Since different regulations of contracts are assumed to affect the behavior of contractor in wasting materials, this parameter was studied. Through a questionnaire survey, wastage of materials in projects employed by cost-plus or lump-sum contract was investigated. This questionnaire asked contractors to determine the contract type and wastage percent of materials in their projects in order to understand the impact of contract type on the amount of construction waste generated in residential projects. The objective of this study was to utilize field studies and surveys in order to enhance the understanding about the impact of contract type on the amount of construction waste generated in residential projects. The study also investigated the impact of contract types on the 


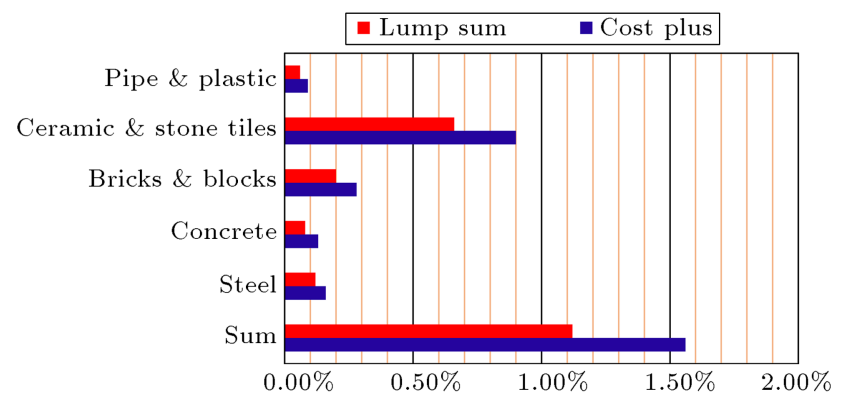

Figure 2. Comparison of the amounts of waste generated in lump-sum and cost-plus projects.

waste minimization and management practices that practitioners adopted in residential projects. The early findings of this research indicated that the contract type had an apparent effect on the amount of construction waste produced in construction project. Figure 2 shows a comparison between the amounts of waste (as a percentage of the total material consumption) generated in LumpSum and Cost-Plus projects. In the later stages of this research, the data would be statistically analyzed to determine whether the effect of contract time on the amount of waste is significant. The results will be interpreted in an effort to identify the key factors contributing to these differences. The averages for wastage of materials in the studied projects are calculated and shown in Figure 2.

b) Appropriate guidelines should be established in order to incorporate waste minimization and management considerations in project planning and permitting process. Preparation of a CWM Plan should begin in the early stages of project development to facilitate efficient and timely management of the waste that is likely to be created during the construction process. It is essential for the parties involved in a construction project to estimate the amount of waste in a construction project and accordingly plan and control the process of managing the generated waste. If developed at the early stages of a project, CWM Plans will help project stakeholders establish goals for the management of construction waste by focusing upon waste minimization, reuse, and recycling opportunities. This will promote sustainable development, environmental protection, and efficient use of resources. A questionnaire was prepared based on Likert scale and was delivered to 50 construction experts. The objective of this study was to develop guidelines on preparation and evaluation of CWM Plans in the early stages of the permitting of construction. The experts were requested to assign one of five scores from 1 to 5 to criteria based on their experience and judgment. A model will be provided to estimate the volume of waste that is expected to be generated during the construction period. Appropriate measures will be introduced to develop and evaluate the plans that are designed to minimize and/or manage the generated waste during the construction process. The permitting agencies such as municipalities can use the outcome of this research to integrate the development of an appropriate CWM Plan as a critical part of the permitting process that all construction projects should pass.

c) Developing an ICWM framework by ranking market prices of waste materials helps to evaluate salvaging of building materials for recycle or reuse and incentives offered in order to design and construct sustainable buildings, infrastructures, and communities that are focused on various means and methods for improving sustainability to ensure the future of the built environment. In order to conduct this study, a list of 21 criteria influencing the amount of generated waste was derived from reviewed literature. Then, a questionnaire survey was done in which 65 construction experts took part. This questionnaire survey was arranged in Likert scale and the experts were supposed to choose one of the scores of $1,2,3,4$, or 5 for each criterion. Data was analysed using AHP. Then, the average of scores for each criterion was calculated and the criteria were ranked according to their final scores. These criteria were categorized in 3 phases of initiating, design, and construction. Determining appropriate contract along with cooperation of design and construction phases was identified as the key factor of controlling construction waste generation. Solid CWM policies can lead to sustainable management practices.

\section{The waste generated in demolition phase}

The goal is to identify market sources for reusable and recyclable materials generated from C\&D projects. Private-sector experience has successfully demonstrated that deconstruction and salvage of building materials are viable alternatives to demolition and landfill in many commercial markets. Under the appropriate conditions, it is realistic to expect more than $75 \%$ of a building's content to be salvaged for reuse or recycling [26].

Figure 3 shows the constituents of $C \& D$ waste in Tehran, Iran.

\section{Discussion}

The target of this study is to depict an inclusive CWM Plan looking at the total life cycle of the project. This holistic approach was called Integrated Construction 


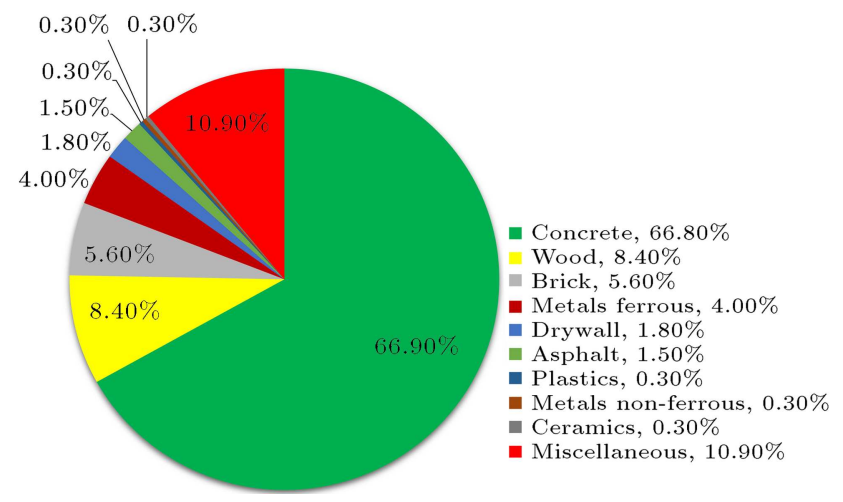

Figure 3. Constituents of construction and demolition waste in Tehran, Iran [26].

Waste Management (ICWM). Construction waste, disposed or not useful material during construction of projects, is one of the most recent environmental concerns. ICWM is balancing of environmental demands of a project with economic ones. In other words, ICWM is a comprehensive construction waste prevention, recycling, composting, and disposal program. One basic necessity of life for human prosperity is maintaining a clean environment; yet the evidence from this analysis suggests that no progress has been made in addressing problems of Municipal Solid Waste Management (MSWM) as the population grows. Physical expansion of the metropolitan region through urban sprawl has occurred without complementary expansion of Solid Waste Management (SWM) services and, indeed, most other services. Evidence from the field suggests that thousands of people in the study area depend on waste management policies. In this paper, previous studies by authors, which were related to identification, management, and reduction solutions of construction waste, are elaborated on, and results of each are discussed.

For example, a model is mapped in Table 2. This model is intended to serve as a standard for project managers to implement CWM program in construction projects. In the process of developing this model, first, the feasibility of adding CWM concepts to environmental management knowledge area was examined. However, the scope of necessary changes as well as the importance and universality of CWM principles required the principles of CWM to be treated as a separate knowledge area of construction extension.

Furthermore, Table 3 summarizes the degree of influence of constructability ideas on productivity. Results indicate that, if conducted during the design phase, constructability reviews could enhance the productivity in high-rise building projects. It is recommended that, prior to the initiation of a project, the project management team develop appropriate guidelines and checklists for conducting constructability reviews.

Since so far no effective policy is implemented in
Iran to reduce construction waste (some regulations are devised just for demolition waste), authors decided to determine the most wasted material and define a financial incentive to control its wastage. As declared in Section 1.2.3 and Table 5, a financial incentive equal to demolition charge will be effective in reducing cement waste.

The results of other studies by authors and other recent studies can be found in the paper and especially in Section 3. To assert briefly, lump-sum contract is more justifiable than cost-plus contract in order to reduce materials waste.

Determining appropriate contract along with cooperation of design and construction phases is identified as the key factor of controlling construction waste generation. Solid CWM policies can lead to sustainable management practices.

\section{Conclusions}

In this paper, an overview of the findings of a broad local research program that has been undertaken over the last several years is presented. The objective of this research program has been identifying and/or developing appropriate waste management procedures and practices that can be implemented throughout the life cycle of the construction project, from planning, design, and construction stages to the renovation or demolition phases.

ICWM can be addressed in two different ways; first, waste minimization and second, waste management; during the whole life cycle of the project, from initiation to demolition. The aim of the first phase of this research program was to identify the sources of waste throughout the supply chain of construction projects and determine appropriate waste management practices to control the generated waste. Several factors were carefully investigated and ranked. In the second phase, several comprehensive studies were conducted in order to find effective ways for CWM during construction, renovation, and/or demolition phases of the projects. Some CWM concepts are suggested to be added to Project Management Knowledge Area (see Table 2) in order to manage and reduce construction waste generated. These suggestions are to be approved by PMBOK Guide board.

This research program has been expanded over the past few years and, at present, there are several ongoing research efforts focusing on CWM. The research is being conducted to understand the impact of project organization factors such as contract type on the amount and characteristics of the waste generated in construction projects. There is another research effort focusing on creating appropriate guidelines to incorporate waste minimization and management considerations in project planning and permitting process. 
It is imperative to conduct more studies on CWM. These research efforts should especially focus on the construction industry in developing economies, where construction works will remain a major economic activity. In future research projects, sophisticated modeling and simulating techniques should be used in conjunction with surveys and case studies in order to enhance the understanding about effective ways to approach CWM.

The main research recommendations are the following:

- It is very important to establish a salvage plan for all materials before starting a project;

- ICWM Plan and its complementary supporting details should provide the roadmap for the execution of the CWM program (for example, it is suggested to convince contractors by economic incentives to minimize the amount of cement they waste during the construction phase of the buildings [9]);

- Achievement of ICWM incentive goals should be included in the project charter;

- ICWM program should require workforce to work more efficiently and neatly;

- Administration and closure should include documenting project results to formalize acceptance of the ideal final result by the project management, governmental authorities, and organizations approving the implementation of ICWM. It includes collecting program records; ensuring that they reflect final specifications; analyzing success and effectiveness of the program, and the lessons learned; and archiving the document for future use;

- Municipal authorities can persuade contractors to reduce the amount of construction waste they generate by means of economic rewards;

- Documented waste management performance should become another pillar of ICWM; and

- Last but not least, educational materials, manuals, and instructions are to be prepared and documented for extensive use.

The following are the benefits of the discussed integrated ICWM Plan:

- Salvaged building materials offer many opportunities to owners, consultants, and contractors for reuse or recycling, including:

- Lower material costs than virgin (e.g., crushed concrete in place of virgin aggregate);

- High-quality building materials;

- Materials that may match historical building elements; and

- Reduced waste disposal costs.

\section{References}

1. Bossink, B.A.G. and Brouwers, H.J.H. "Construction waste: quantification and source evaluation", Journal of Construction Engineering and Management, 122(1), pp. 55-60 (1996).

2. Bossink, B.A.G., Brouwers, H.J.H. and Kessel, R.V. "Financial consequences of construction waste", In Proc CIB W98 Beijing Int. Conf., Oct., pp. 1-6 (1996).

3. Begum, R.A., Siwar, C., Pereira, J.J. and Jaafar, A.H. "Implementation of waste management and minimisation in the construction industry of Malaysia", Resources, Conservation and Recycling, 51(1), pp. 190-202 (2007).

4. Li, Y., Zhang, X., Ding, G. and Feng, Z. "Developing a quantitative construction waste estimation model for building construction projects", Resources, Conservation and Recycling, 106, pp. 9-20 (2016).

5. Li, J., Tam, V.W.Y., Zuo, J. and Zhu, J. "Designers' attitude and behaviour towards construction waste minimization by design: A study in Shenzhen, China", Resources, Conservation and Recycling, 105, pp. 29-35 (2015).

6. Parkes, O., Lettieri, P. and Bogle, I.D.L. "Life cycle assessment of integrated waste management systems for alternative legacy scenarios of the London Olympic Park", Waste Management, 40, pp. 157-166 (2015).

7. Rigamonti, L., Sterpi, I. and Grosso. M. "Integrated municipal waste management systems: An indicator to assess their environmental and economic sustainability", Ecological Indicators, 60, pp. 1-7 (2016).

8. Herva, M., Neto, B. and Roca, E. "Environmental assessment of the integrated municipal solid waste management system in Porto (Portugal)", Journal of Cleaner Production, 70, pp. 183-193 (2014).

9. Mahpour, A. and Mortaheb, M.M. "A new pattern for controlling construction waste, an approach toward sustainable development", M.Sc. Thesis, Faculty of Civil Engineering, Sharif University of Technology, Tehran, Iran (2015).

10. Mortaheb, M.M. and Kavousian, A. "Construction and demolition waste production and management in developing countries (A case study: Tehran metropolitan, Iran)", Proceedings of CSCE-Canadian Society of Civil Engineers Conference, Yellowknife, Northwest Territories, June 6-9 (2007).

11. Rezayi, M. and Mortaheb, M.M. "Investigation of construction waste generation in residential buildings, case study of lump sum and cost plus contracts", M.Sc. Thesis, Faculty of Civil Engineering, Sharif University of Technology, Tehran, Iran (2014).

12. Mahpour, A., Mortaheb, M.M. and Sebt, M.H. "Evaluating the effect of financial incentive on construction waste generation in Tehran's residential buildings", Proceedings of the 11th International Project Management Conference, Tehran, Iran, 13-14 February (in Persian) (2016). 
13. Brundtland, G.H., World Commission on Environment and Development: Our Common Future, p. 16 (1987).

14. Ruwanpura, J., Prado, B. and Hettiaratchi, P. "A computer simulation model to predict waste generation and promote sustainable construction practices at construction sites", In Canadian Society for Civil Engineering-31st Annual Conference: 2003 Building our Civilization, June 4, 7, pp. 499-508 (2003).

15. Dolan, P.J., Lampo, R.G. and Dearborn, J.C. "Concepts for reuse and recycling of construction and demolition waste", (No. CERL-TR-99/58), Construction Engineering Research Lab (Army) Champaign Il (1999).

16. Kern, A.P., Dias, M.F., Kulakowski, M.P. and Gomes, L.P. "Waste generated in high-rise buildings construction: A quantification model based on statistical multiple regression", Waste Management, 39, pp. 3544 (2015).

17. Sáez, P.V., Porras-Amores, C. and Merino, M.D.R. "New quantification proposal for construction waste generation in new residential constructions", Journal of Cleaner Production, 102, pp. 58-65 (2015).

18. Ding, T. and Xiao, J. "Estimation of buildingrelated construction and demolition waste in Shanghai", Waste Management, 34, pp. 2327-2334 (2014).

19. Li, J., Ding, Z., Mi, X. and Wang, J. "A model for estimating construction waste generation index for building project in China", Resources, Conservation and Recycling, 74, pp. 20-26 (2013).

20. Banias, G., Achillas, C., Vlachokostas, C., Moussiopoulos, N. and Papaioannou, I. "A web-based decision support system for the optimal management of construction and demolition waste", Waste Management, 31, pp. 2497-2502 (2011).

21. Llatas, C. "A model for quantifying construction waste in projects according to the European waste list", Waste Management, 31, pp. 1261-1276 (2011).

22. Cochran, K.M. and Townsend, T.G., "Estimating construction and demolition debris generation using a materials flow analysis approach", Waste Management, 30, pp. 2247-2254 (2010).

23. Katz, A. and Baum, H. "A novel methodology to estimate the evolution of construction waste in construction sites", Waste Management, 31, pp. 353-358 (2010).

24. Udawatta, N., Zuo, J., Chiveralls, K. and Zillante, G. "Improving waste management in construction projects: An Australian study", Resources, Conservation and Recycling, 101, pp. 73-83 (2015).

25. Butera, S., Christensen, T.H. and Astrup, T.F. "Life cycle assessment of construction and demolition waste management", Waste Management, 44, pp. 196-205 (2015).

26. Kavousian, A. and Mortaheb, M.M. "Construction waste management an approach to improve construction productivity", Undergraduate Research Project, Civil Engineering Department, Sharif University of Technology, pp. 1-200 (2007).

27. Construction Industry Institute, Constructability: A Primer., Austin Texas, Construction Industry Institute (1986).

28. Construction Industry Institute Australia, Constructability Principles File, University of South Australia, Sydney (1992).

29. Russell, J., Swiggum, K., Shapiro, J. and Alaydrus, A. "Constructability related to TQM, value engineering, and cost/benefits", J. Perform. Constr. Facil., 8(1), pp. 31-45 (1994).

30. Abrishami, A. and Mortaheb, M.M. "Effect of constructability studies at design phase on construction productivity and waste reduction", M.Sc., Department of Construction Management, Science and Research Branch of Islamic Azad University, pp. 1-230 (2008).

31. Zekavat, P., Mortaheb, M.M., Han, S. and Bernold, L. "Comparative study of GPS-integrated concrete supply management using discrete event simulation", Journal of Construction Engineering and Project Management, 4(2), pp. 31-40 (2014).

32. Kanafani, A., Transportation Demand Analysis, McGraw-Hill Series in Transportation, USA, pp. 3045 (1983).

33. Winebrake, J.J., Green, E.H., Comer, B., Li, C., Froman, S. and Shelby, M. "Fuel price elasticities for single-unit truck operations in the United States", Transportation Research Part D, 38, pp. 178-187 (2015).

34. Khiabani, N. and Hasani, K. "Technical and allocative inefficiencies and factor elasticities of substitution: An analysis of energy waste in Iran's manufacturing", Energy Economics, 32, pp. 1182-1190 (2010).

35. Mansikkasalo, A., Lundmark, R. and Söderholm, P. "Review market behavior and policy in the recycled paper industry: A critical survey of price elasticity research", Forest Policy and Economics, 38, pp. 1729 (2014).

36. Tam, V.W.Y. and Tam, C.M. "Waste reduction through incentives: A case study", Building Research \& Information, 36, pp. 37-43 (2008).

\section{Biographies}

Mohammad Mehdi Mortaheb received his $\mathrm{PhD}$ in Construction Materials and Management from University of Kentucky, Lexington, KY, USA, in 1990. He has been a member of scientific committees of several national and international conferences related to project and construction management and supervised many graduate students doing their master degrees at Sharif University of Technology (SUT) and other universities. He has been active in directing and managing different 
real projects, especially in pipe line, oil, gas, and petrochemical industries of Iran, over the last 42 years. He has been always a bridge between academy and industrial world.

Amirreza Mahpour received his BSc degree from Amirkabir University of Technology (AUT), Tehran,
Iran, in 2014. He has been MSc student of Construction Engineering and Management in Civil Engineering Department of Sharif University of Technology (SUT), Tehran, Iran, since 2014. His research is within the field of construction and demolition waste management and devising policies to control and reduce this kind of solid waste. 